\title{
An Assessment of 'Tradermoni' Empowerment Scheme in Nigeria from the Islamic Perspective: A Case Study of Women Beneficiaries at the Mandate Market, Ilorin
}

\author{
Abdus-Samii Imam Arikewuyo, Ph.D ${ }^{1^{*}}$, Salihu Muhammad Akanbi ${ }^{2}$
}

${ }^{1}$ Associate Professor (Islamic Studies) Department of Religions, History and Heritage Studies Kwara State University, Malete

${ }^{2}$ Postgraduate Research Student Department of Religions, History and Heritage Studies Kwara State University, Malete

DOI: $10.36348 /$ sjhss.2020.v05i02.005 $\quad$ |Received: 10.02 .2020 |Accepted: 18.02 .2020 | Published: 27.02 .2020

*Corresponding author: Abdus-Samii Imam Arikewuyo, Ph.D

\section{Abstract}

It is incontrovertible that poverty is the major bane of the Nigerian nation. Invariably, it engenders series of socioeconomic and political menace in the society such as corruption, money rituals, kidnapping as well as various cybercrimes all in a bid to get rich soonest. The most vulnerable citizens that are worst hit by this criminality are the women and children. Hence, prevalence of their involvements as victims of kidnapping, rituals and sex related mishaps. This development posed challenges to the government and the citizens. Hence, over time, efforts were made by the government through various approaches to address the poverty issues in Nigeria. Prominent among such strategies in the past was the introduction of Operation Feed the Nation, Structural Adjustment Programme, the National Directorate of Employment, the Family Support Programme, and National Poverty Eradication Programme etc. Moreover, the present government initiates various schemes under its Social Investment Programme which include N-Power, Home Grown School Feeding, 'TraderMoni' and a host of others for the purpose of empowerment and poverty reduction. The paper is however focused on an assessment of the 'TraderMoni' scheme for economic empowerment of the women beneficiaries at the Mandate Market, Ilorin with a view to determining its validity, strength and limitations from the Islamic perspective. Findings indicate that the 'TraderMoni' scheme generates empowerment for petty traders in Nigeria; its objective is laudable and Islamically acceptable but its execution was beset with multifarious challenges. The research employed interview, focus group discussion and literary analysis. The paper concludes with recommendations that efforts should be made by the government to sustain the 'TraderMoni' loan scheme with transparency and strict adherence to the terms of the contract with a view to eradicating poverty in the Nigerian society.

Keywords: 'TraderMoni' Scheme; Women beneficiaries; Empowerment; Mandate Market, Ilorin.

Copyright @ 2020: This is an open-access article distributed under the terms of the Creative Commons Attribution license which permits unrestricted use, distribution, and reproduction in any medium for non-commercial use (NonCommercial, or CC-BY-NC) provided the original author and source are credited.

\section{INTRODUCTION}

Nigeria is renowned as the giant of Africa given its population strength, natural resources and human capital endowment. The country is the most populous in Africa and the seventh in the world population ranking [1]. Statistically, Nigeria's population, as at 2018 , is estimated to be 180 million out of which 86.9 million representing nearly fifty percent live in extreme poverty[2]. Absolute poverty in this regard is determined by the number of people who can afford the basic essentials of shelter, food and clothing. The poverty rate over time constitutes nuisance on the path of national development; hence, each successive government did not relent on its oars to lift more citizens out of the extreme poverty. Towards realization of this goal, the governments had embarked on various socio-economic programmes to alleviate poverty in Nigeria; but no substantial success was ever made in this direction. Some of the socio-economic programmes that were evolved by successive Nigerian governments in the past towards poverty reduction included: Operation Feed the Nation (OFN) in 1976, the Agricultural Credit Guarantee Scheme in 1977, Structural Adjustment Programme (SAP) in 1986, the National Directorate of Employment (NDE) in 1986, the Family Support Programme (FSP) in 1994, the Family Economic Advancement Programme (FEAP) in 1997, Poverty Alleviation Programme (PAP) in 1999, National Poverty Eradication Programme (NAPEP) in 2001 and the Seven-Point Agenda in 2007 among several others. It is manifest that there had been overlap of intervention strategies and the target groups, lack of continuity of programmes and abrupt termination of 
some before attaining the desired goals due to change of government[3]. Besides, the failure of some of the programmes was not unconnected with insincerity of the government and overwhelming corruption of the stakeholders. While some of the programmes have been successful, the overall idea of combating poverty has not been sustainable as the menace remains a challenge in the country [4].

In furtherance of government's attempt to eradicate extreme poverty in Nigeria, one of the flagships of the present administration, led by President Muhammadu Buhari, is the Social Investment Programme (SIP). This suit of programme, developed in 2015, primarily draws on what had been proclaimed in the All Progressive Congress (APC) campaign manifesto. It comprises mainly of the $\mathrm{N}$-power programme, the National School Feeding programme, the National Cash Transfer programme and the Government Enterprise and Empowerment programme[5]. Broadly, the SIP is aimed at responding to the challenge of poverty, inequality and unemployment in the country by implementing programmes to help improve livelihood for the poor, improve access to health and education, reduce youth unemployment, eradicate child malnutrition, improve financial inclusion through better access to credit for Micro, Small and Medium Enterprises (MSMEs) and promoting productivity[6]. The Government Enterprise and Empowerment Programme (GEEP) has several empowerment windows which include Presidential Youth Empowerment Scheme (P-YES), Youth Empowerment and Development Initiative (YEDI), African Youth Empowerment in Nigeria (AYEN), Youth Entrepreneurs of Nigeria (YEN), Youth Empowering People (YEP), Youth Entrepreneurial Support Project (YES-P)[7] etc. It is discernible that most of these empowerment programmes are youth oriented and require some level of educational attainments for eligibility. Others include FarmerMoni, MarketMoni and 'TraderMoni'. The fact that women constitute the vulnerable gender in the society across the globe with outrageous poverty level and that the 'TraderMoni' scheme has direct bearing on the Nigerian petty market women without any stringent condition informed the choice of 'TraderMoni' for the present study. The paper focusses on an assessment of the 'Trader Moni' scheme for economic empowerment of the women beneficiaries at the Mandate Market, Ilorin with a view to determining its validity, strength and limitations from the Islamic perspective. It, therefore, expatiates on the concept and objective of the 'TraderMoni' scheme; explores implementation of the scheme in Nigeria; identifies the Islamic provisions on economic empowerment and makes a critique of the 'TraderMoni' scheme for economic empowerment of the women vis-a-vis Islam using the Mandate Market, Ilorin beneficiaries as a case study. Invariably, the paper recommends that efforts should be made by the government to sustain the 'TraderMoni' loan scheme with transparency and strict adherence to the terms of the contract with a view to eradicating poverty in the Nigerian society.

\section{Concept and Objective of 'TraderMoni' Empowerment} Scheme

'TraderMoni' scheme is one of the federal government social investment programmes that focused on how best to improve and empower petty traders and artisans in Nigeria. It is a loan programme of the Federal Government, created specifically for petty traders and artisans across the country as a part of the Government Enterprise and Empowerment Programme (GEEP) scheme being executed by the Bank of Industry. With 'TraderMoni', a beneficiary receives interest-free loans starting from N10, 000 and graduates all the way to N100, 000 in five prescribed installments upon liquidation of one loan before taking another. A loanee is entitled to $\mathrm{N} 10,000$ as the initial loan and thereafter qualifies for N15, 000 as the second loan; then N20, 000 as the third; N50, 000 as the fourth and $\mathrm{N} 100,000$ as the fifth provided he was faithful to the repayment obligations accordingly [8]. Each loan is scheduled to be liquidated within six (6) months and refund is spread on weekly or daily basis as might be convenient to the loanee.

It is pertinent to observe that 'TraderMoni' is similar to MarketMoni which is another cash transfer loan scheme of the Federal Government under the same Social Investment Programmes, but they are not necessarily the same. While Marketmoni loan starts at N50, 000 for the benefit of the Small and Medium Enterprises (SMEs) traders, market women, artisans, and youth in market associations, the 'TraderMoni' loan on the other hand starts at N10, 000 for micro businesses which targets petty traders and petty artisans [9]. Essentially, the scheme allows the Federal Government to respond to the plight of substantial population of Nigerians in petty business who are in dire need of capital to grow their businesses but have no opportunity to access loans to trade; hence, they remain in a cycle of poverty. Thus, the Federal Government's objective of the 'TraderMoni' is to change the socioeconomic status of the downtrodden but hardworking Nigerian citizens by providing them with continuous loans for their petty businesses, making each loan bigger to enable them grow. The goal was to help improve financial inclusion by providing small loans to small scale traders, artisans and entrepreneurs [10]. The scheme offers opportunity to help a micro business become viable business thereby strengthening the economy. Furthermore, it aims at providing succour and welfare to the vulnerable groups in the society through economic empowerment.

An economic empowerment programme is conceived as an intervention project which is aimed at providing an individual with economic independence, sustenance and advancement. Economic empowerment 
programmes are therefore designed to increase the degree of autonomy and self-determination of the people by equipping them with knowledge and/or financial requirements to excel in a specific career [11]. The place of economic empowerment cannot be overemphasized especially when it leads to increase in employment and improvement in opportunities for productive activities among the poor masses [12]. Considering the vulnerability and overwhelming population of women in most societies of the world, they are found to be more suited for such economic intervention. It is obvious that when a substantial part of the population cannot compete equitably or realize its full potential, the national economy suffers it. Hence, there is increasing recognition that to economically empower women is essential both to realize women's rights and to achieve broader development goals such as economic growth, poverty reduction, health, education and welfare [13]. The economic empowerment promotes women's ability to achieve their rights and well-being while it also reduces household poverty, increases economic growth and productivity as well as efficiency. When women have the right skills and opportunities, they can help businesses and markets grow predicating their contributions to the family, society and national economy. This philosophy is in tandem with the objective of the 'TraderMoni' scheme. Thus, the target beneficiaries of 'TraderMoni' loans are the petty traders, small kiosk owners, food stuff sellers, bread sellers, pepper sellers, vegetable sellers, meat sellers, roadside corn sellers, akara (fried beans) sellers, groundnut sellers, plantain sellers, mai shai (roadside tea men), wheel barrow pushers, mobile tailors, mobile cobblers, fruits sellers, keke (cycle) riders etc. It is noteworthy that other than few of these trades which are exclusive for men, women constitutes majority of the petty traders in the market. Hence, the study focusses on women as the majority beneficiaries of the 'TraderMoni' empowerment scheme vis-à-vis Islamic provisions.

\section{An Over-view of the Implementation of 'TraderMoni' Scheme in Nigeria}

The poverty status of Nigeria had been critically examined in previous research works; one of which indicates unceasing increase in her poverty rate, with due recognition to regional variations, over the years [14]. It is on record that Nigeria ranked 152 of 157 countries in the World Bank's 2018 Human Capital Index [15]. Poverty is defined as "the state of being extremely poor" or "the state of being inadequate in quality or amount"'[16]. Thus, poverty is generally conceived from two different perspectives, namely: moneylessness and powerlessness. "Moneylessness" means both an insufficiency of cash and chronic inadequacy of resources of all types to satisfy basic human needs, such as, nutrition, rest, warmth and body care while "powerlessness" is lack of opportunities and choices as are open to the non-poor. Thus, life of the powerless people seems to be governed by persons and forces outside their control as typified by people in positions of authority, perceived evil forces or hard luck [17]. The focus in this paper, however, is on moneylessness; the menace of which is manifest in lack of income and productive resources sufficient to ensure sustainable business and livelihood, hunger and malnutrition, ill-health, increased morbidity and mortality from illness etc. In the incidence of any of these anomalies, women are the worst hit. It is in the light of this fact that the 'TraderMoni' was conceived and initiated as a means of empowerment for the impoverished citizens.

The 'TraderMoni' scheme is entrenched in the Government Enterprise Empowerment Programme (GEEP) which is one of the major components of the National Social Investment Programmes (NSIP) approved by the National Assembly with appropriation bill in 2016[18]. Other projects in this category approved by the National Assembly include the NPower initiative, MarketMoni, FarmerMoni and Home Grown School Feeding etc [19] all of which had taken off earlier. The 'TraderMoni' scheme was launched by the Federal Government of Nigeria in phases in partnership with the Bank of Industry (BoI) in order to enlarge government's financial inclusion agenda to embrace the Nigerian citizens at the grassroots considering their contributions to economic development of the nation. The micro-credit scheme was flagged off in Lagos on $7^{\text {th }}$ August, 2018 in five markets at Ketu, Mushin, Ikorodu, Agege and Abule Egba[20]. Subsequently, it got extended to other states of the federation in quick succession with the aspiration to empower two million people across the 36 states and the Federal Capital Territory (FCT) between August and December, 2018[21]. However, while a larger number of states were covered with the estimate of 1.5 million beneficiaries within the record time, the backlog that could not be covered as proposed was deferred and got accomplished by the mid-2019[22]. The project, whose launch was spearheaded by the Vice President, Professor Yemi Osinbajo in major markets across the country was overwhelmingly applauded by market women especially the petty traders and low profile marketers. Yet, the scheme did not go uncriticized especially by the political opponents who claimed that the 'TraderMoni' was a political inducement for vote buying [23].

The 'TraderMoni' scheme was designed to be access-friendly to the prospective beneficiaries. It is collateral free and devoid of bureaucracy that could breed frustration in the process of accessing it. Many traders were largely encouraged by the ease of access to the loan. All that the prospective loanee needs to do is to get registered by the accredited activation agents in the markets or through an online application. The activation agents are composed of both the enumeration and cash disbursement teams. The registration format simply requires supply of correct information on the 
names, identity and mobile phone number of the applicant which serves as the "wallet"[24]. The information is verified to confirm that the applicant is a Nigerian; he/she is 18 years and above; a business owner or a trader; a member of the market co-operative union in his/her location; has a valid identification; has a valid SIM/ Phone number that is registered with the service providers and a valid Bank Verification Number (BVN)[25]. Since the loan scheme is cash and carry in the first instance, the BVN requirement is deemed applicable to loanees for subsequent loan instalments. Upon certification of the requirements and approval accordingly, the individual's "wallet" is credited instantly with the initial loan grant of N10, 000 for 'TraderMoni' scheme. The beneficiary has the option to cash out this money either from the bank (if he/she already has a bank account) or from registered agents. Upon successful repayment of the first loan, the beneficiary is automatically qualified for subsequent loans of N15, 000; N20, 000; and N50, 000 in turns after which he is entitled to N100, 000 and thereby graduates to MarketMoni group imperceptibly.

The 'TraderMoni' scheme allows for a flexible weekly loan repayment plan over a six months period for each loan. The repayment schedule is as follows [26]:

\begin{tabular}{|c|c|c|}
\hline Loan & Weekly Repayment & Total \\
\hline N10,000 & N430 24 & N10, 250 \\
\hline N15,000 & N640 24 & N15, 375 \\
\hline N20, 000 & N875 24 & N21, 000 \\
\hline N50,000 & N2, 187 24 & N52, 500 \\
\hline
\end{tabular}

Apparently, there is a difference between the amount of loan and the refund in each case which ranges between $2.5 \%$ and $5 \%$. The payment is authorized to be made through either designated banks or accredited 'TraderMoni' agents within the reach of the loanee. The approved banks are: Union Bank, Wema Bank, Guarantee Trust Bank, United Bank for Africa, Ecobank, Fidelity Bank, Sterling Bank, Heritage Bank and Jaiz Bank [27]. The Bank of Industry, as the coordinating bank, further introduced the use of scratch cards to facilitate stress free repayment by the beneficiaries regardless of the individual's location [28].

\section{Islamic Provisions on Economic Empowerment}

Islam puts machineries in place to instigate economic independence and sustenance of its adherents. Hence, it prescribes individual's rights to economic possessions through acquisition, transfer and inheritance [29]. Possessions by acquisition are obtainable through kasb (labour), buyu (commercial transactions), shirkah (partnership), shufah (preemption), wakalah (agency) etc. For purpose of elucidation, kasb is here considered as a case study for further exposition. Kasb refers to all the sundry means embracing labour, professional trade, arts and crafts through which an individual could legitimately earn a livelihood. Its place as a means of economic empowerment in Islam is encapsulated in the contractual undertaking between Prophets Musa and $\mathrm{Shu}^{\mathrm{c}}$ ayb whereby the former was engaged in service by the latter with a view to empowering him[30]. The Qur'an therefore reads thus:

And said one of them (the two women): "O my father! Hire him! Verily, the best of men for you to hire is the strong, the trustworthy. He said: "I intend to wed one of these two daughters of mine to you, on condition that you serve me for eight years; but if you complete ten years, it will be (a favour) from you. But I intend not to place you under a difficulty. If Allah wills, you will find me one of the righteous". He (Musa) said: "That (is settled) between me and you: whichever of the two terms I fulfill, there will be no injustice to me, and Allah is Surety over what we say" (Q. 28: $26-28)$.

The Qur'an commentators hold that Musa was engaged as a flock rarer in the service of $\mathrm{Shu}^{\mathrm{c}}$ ayb for ten years [31]. The Qur'an contains further references on the essence of exploration of the universe by man for the purpose of empowerment to earn livelihood (Q. $4: 32 ; 67: 15$ and 71:19-20). To corroborate the place of $k a s b$ as a means of economic empowerment, it should be recalled that Prophet Muhammad (SAW) was himself a flock rarer and sales agent while he also acknowledged that Prophet Zakariya' was a carpenter and that Prophet Dawud lived on earnings from his handiwork[32]. Hence, he exhorted thus:

It is better that one of you should take up his cords, go to the mountain, carry a pile of wood on his back, sell it and thereby earn a living to secure himself against the chastisement of Allah ...[33].

The fore-going entrenched the essence of personal handiwork, professional trade, arts and crafts for self-empowerment economically.

Empowerment through possessions by transfer could be obtained through hibah (gift), sadaqah (alms or charity), zakat (legal almstax), mahr (dower), nafaqah (maintenance), waqf (endowment), cariyyah/qard (loan), rahn (mortgage) etc. The philosophy and decree on the distribution of zakat as prescribed in Islam (Q. 9:60) allude to its credibility as a means of investment and economic empowerment [34]. Moreover, the advocacy of Islam on wealth circulation (by means of charity, gifts and loans etc.) generally encourages empowerment through transfer of wealth as against its concentration in the hands of the few privileged ones. In addition, possessions through wirathah (inheritance) is decreed in favour of the legitimate heirs regardless of sex upon the death of 
one's relative by means of which the heirs are empowered and relieved from socio-economic distress consequential to death of the deceased.

The fore-going order provides a sustainable structure for economic empowerment in respect of all and sundry. Exclusively however, women enjoy empowerment opportunity through the receipt and proper utilization of the mahr (dower) and nafaqah (maintenance) that they benefit from their husbands [35]. Thus, the concept of women empowerment from the Islamic view-point is the process of paving ways in which the possession of different types of economic wealth and/or intellectual resources can be adopted by the women to better their lots. The empowerment thus ensures the establishment of autonomy of the women but without prejudice to the authority of "men as the protector of women" (Q. 4:34). The goal of women empowerment is to afford them opportunity to take part in the household decision making and to independently control the productive resources owned by them. This explains the relevance of the 'TraderMoni' scheme in empowering the women petty traders. At any rate, it is note-worthy that the extent that many women pursue economic possessions in the contemporary time by which they compete vigorously and endlessly with the male counterpart is at variance with the Islamic provisions on economic empowerment of women.

\section{'TraderMoni' Empowerment Scheme and the Women Beneficiaries at the Mandate Market: A Critique from the Islamic Perspective \\ The 'TraderMoni' scheme was launched in} Ilorin on $7^{\text {th }}$ December, 2018[36]. The exercise was initially scheduled to hold in two major markets in Ilorin, the Kwara State capital. The designated markets were Mandate Market in Ilorin West Local Government Area and Ipata Market in Ilorin East Local Government Area. Marketers trooped out en masse to register for the exercise in the two markets but political thugs virtually disrupted the launch proper at the Mandate Market ahead of the arrival of the Vice President, Yemi Osinbajo who was to launch the programme[37]. Nonethe-less, the task of enumeration of participants and loan disbursement was accomplished at both the Mandate and Ipata Markets. Out of the two markets, the former is chosen for the present study because its establishment was more recent than the other and it is a fast growing modern market with variety of businesses and entrepreneur compared to the latter which is ancient and choked up with less commercial varieties. A total of Two Hundred (200) petty traders were recorded to have registered and benefitted the micro-credit 'TraderMoni' loan at the Mandate Market, Ilorin. The beneficiaries were One Hundred and Forty (140) females and sixty (60) males, that is, $70 \%$ and $30 \%$ respectively [38]. The female beneficiaries included 20 petty traders; 30 micro scale food stuff sellers; 20 condiments sellers; 10 fish traders; 10 meat traders; 10 vegetable sellers; 10 palm oil and groundnut oil retailers; 5 beans cake (akara) sellers; 5 roasted plantain sellers; 5 bread sellers; 5 fruit sellers; 5 pop-corn sellers and 5 pure water sellers totaling 140 . Out of these beneficiaries, sixty (60) were selected randomly across the business varieties as study cases in this work. The research was conducted among them through interview and focus group discussion. Findings revealed that the 'TraderMoni' loan scheme provided the women beneficiaries with the desired economic empowerment to create wealth, sustain their businesses and improve on their sources of livelihood. Although, the scheme had been widely criticized by some individuals as politically inclined for vote buying and that the initial loan of N10, 000 grant was meagre [39] majority of the beneficiaries applauded the giant stride of the Government to cater for them and acknowledged that the loan had positive impact on making their business grow. Most of the respondents revealed that the seed money for their businesses ranged between N2, 500 and N7, 000 at commencement; while in peculiar cases, business took off on credit based on personal recognition between wholesale traders and retailers. Thus, the loan of N10, 000 availed them opportunities for higher commercial value and inducement of change in their own lives as envisaged by the philosophy of economic empowerment.

The 'Trader Moni' loan scheme aligns with the Islamic provisions on loan as an approved source of economic empowerment. The concept of giving loans as a commendable act is contained in several Qur'anic verses (Q. 2:245; 57:11 and 18; 64:17) while the legitimacy of acquiring it is implied in the divine injunctions guiding the contract of debts (Q. 2: 280, 282-283). Since debts basically accrue through loans, the injunctions invariably uphold the acceptability of loan contract in Islam. Gratuitous loans are, in Islamic terminology, termed as ${ }^{c}$ Ariyyah or Qard. ${ }^{c}$ Ariyyah refers to a usufructuary loan which requires the loanee to benefit from the use of the loaned object and return same to the lender afterwards[40]. This applies to the loan of a tangible property such as working implements, books, items of furniture, means of transportation etc. On the other hand, Qard is the loan of a consumable item whose value, rather than the object in its original form, shall be returned as at when due [41]. This appertains to consumption or production loans that involve money, food items, seedlings etc. Since these are consumable items, refund of the loan is made on its value rather than by the loaned object [42]. Apparently, the 'TraderMoni' loan scheme which offers microcredit loans to its beneficiaries falls into this second category, Qard ( consumption/production loans).

Consumption loans are acquired for meeting indispensable minimum wants which constitute basic needs of sustenance while production loans are acquired for industries, working capital or equipments in order to stimulate production and supply. Both the consumption and production loans are recognized in Islam as necessary contingencies in human endeavours. To 
regulate the loan contract, the Islamic law acknowledges four principles; namely: principles of genuineness, principle of contract, principle of payment and principle of help [43]. These principles constitute the basis of assessment of the 'TraderMoni' scheme and empowerment of the women beneficiaries in this paper.

That Islam admits loan acquisition subject to genuineness of its motive and needs cannot be overemphasized. In the light of this, the objective of mounting the 'TraderMoni' scheme to provide economic independence, sustenance and advancement for the beneficiaries is considered laudable. It tallies with the Islamic welfarism especially as it relates to the market women who were found to be the most vulnerable in Ilorin community. This opportunity reduces the menace of poverty in the society which includes awkward matrimonial relationship in some families because of over-dependence on the meagre resources of the spouse, promiscuity, indulgence in social vices, poor health and malnutrition etc. The 'TraderMoni' scheme facilitates the women beneficiaries to support their husbands in family maintenance. Besides, it enables them to provide basic needs for their children and fulfil other personal obligations which hitherto plunged them into debts and social embarrassments. Although, in Islam, the responsibility of family maintenance is obligated on the husband; it is not objected however that the wife gives a helping hand where necessary to complement the husband. This kind gesture is geared towards sustaining mutual love, affection and harmony in the family. The wife could only do this if she is economically empowered. Thus, acquisition of the 'TraderMoni' loan based on the need to support the family is genuine.

The legitimacy of loan contract is affirmed by the Qur'anic injunctions concerning the documentation, refund and/or remission of debts (Q. 2:280, 282 and 283). These Qur'anic decrees are sufficiently corroborated by Prophet Muhammad (SAW)[44]. All the injunctions are with a view to providing guidelines for meeting the demands of the principles of contract and payment of loans. By these provisions, Islam seeks to protect the interest of the debtor against exploitation and that of the creditor against fraudulence. It is clear from the injunctions that Islam requires fulfilment of contractual obligations, advocates documentation of debt (i.e. loan) contracts and urged repayment accordingly. Given this premise as paradigm, the enumeration and registration procedure for the 'TraderMoni' loans conform to the documentation advocacy of Islam. However, as simple as the registration procedure for the 'TraderMoni' scheme was, there were claims of corruption and the 'Nigerian' factors at work. It was observed that in some cases registration was based on favouritism or money inducement illegally received from desperate clients by some officials [45]. This misdemeanor in the first place contradicts the conditions stipulated for the contractual obligation which is indiscriminate of any Nigerian citizens who is a petty trader in the market as a qualified beneficiary of the 'TraderMoni' loans. It is note-worthy that this fraudulent practice was however encouraged by the restriction of targeted beneficiaries to a limited number which invariably necessitated scrambling for registration. Moreover, there was no proper verification of the claims made by some beneficiaries concerning their businesses or trade. Hence, the scheme underwent misappropriation in some cases as typical in the instance of an officially employed guard man in government service who got registered and secured the 'TraderMoni' loan [46].

Furthermore, the micro-credit scheme which was proclaimed to be collateral and interest free attracted an increase in the refund to the tune of $2.5-$ $5 \%$ at the end of the repayment of the loan. The difference which was though tagged as administrative charges is considered in this paper as an aberration since it was not so declared as part of the terms of the contract $a b$ initio. Hence, this act is a manifestation of what the Islamic law referred to as riba an-nasi'a (interest on lent money)[47]. Islam prohibits riba outright (Q. 2: 275) because it exploits the poor and compounds their financial problems. Thus, in Islam, loans are more of grants-in-aid but not a profit-oriented commercial venture. Although, the 'TraderMoni' loans fulfils the principle of help within the context of grantsin-aid by providing the market women with small loans to induce their financial inclusion, the scheme derailed in operation from its interest free proclamation making it a violation of the Islamic law.

It is discernible that despite the strategies designed for ease of refund of the loans, the 'TraderMoni' scheme has not put any machinery in place to check defaulters. The only penalty is for a defaulter to forfeit his/her legitimacy to subsequent loans. Apparently, this laxity undermines the sustainability and durability of the scheme. Assuming a hundred beneficiaries fail to make a refund of N50, 000 loan granted to each of them; merely forfeiting the chance to receive the next loan has no adverse effect on them since there is no specified approach to reprimand and/or apprehend them. Conversely, the government loses a whopping sum of N5, 000,000 at a go on one hand and other prospective beneficiaries might be denied access to the loan on the other. Besides, indulgence of the defaulters negates the prescriptions of Islam on the chastisement of debtors which was signified by the objection of Prophet Muhammad (SAW) to leading the funeral prayer of a debtor on the ground of his debt[48]. Invariably, it is worth noting that there is no record of default among the women beneficiaries at the Mandate Market presently; but there is no assurance that the commitment of the loanees would remain the same as to avoid default in the nearest future. 


\section{CONCLUSION}

The paper has dwelt on the phenomenon and objective of the 'TraderMoni' initiative introduced by the Federal Government of Nigeria in 2018 as a mechanism to engender financial inclusion of the daily hardworking Nigerians who occupied the lowest stratum of the economic ladder. The scheme was launched in selected major markets across the 36 states of Nigeria and the Federal Capital Territory. The thrust of the paper is an assessment of the 'TraderMoni' scheme for economic empowerment of the women beneficiaries at the Mandate Market, Ilorin within the purview of the Islamic provisions.

It was observed that the 'Trader Moni' falls within the framework of Qard (consumption and production loans) in Islam. Therefore, the paper examined the concept and objective of the 'TraderMoni' scheme, process of registration of beneficiaries, the operation and benefits of the scheme, and its strength and limitations in the light of Islam. It was established that the concept and objective of the 'TraderMoni' as a micro-credit loan to help improve financial inclusion with a view to grow micro businesses and provide welfare for women is in consonance with the approval of Islam for consumption and production loans towards meeting indispensable minimum wants and boosting production and supply. The paper highlighted four principles of the Islamic law that regulate loan contract and applied them as paradigm for assessment of the 'TraderMoni' scheme and empowerment of the women beneficiaries at Mandate Market, Ilorin. In consonance with the Islamic principles, the 'TraderMoni' loan is based on genuine needs in terms of its concept and objective of stimulating economic independence, sustenance and advancement of the beneficiaries. Moreover, the scheme fulfilled the aspirations of the principles of contract, payment and help prescribed by Islamic provisions on loan contract. Thus, it is discernible that this opportunity empowered the women beneficiaries to contribute meaningfully to the development of the home and the society at large. Furthermore, it reduces the menace of poverty among the women beneficiaries in Ilorin.

None-the-less, apparent violations of the Islamic rules were identified in respect of corruption in the registration process, lapses in execution and loose re-payment strategies of the 'TraderMoni' loans. Invariably, there were loopholes for favouritism, default in repayment and excess of $2.5-5 \%$ on refund which is a manifestation of riba (interest) contrary to the consideration of the scheme as an interest free loan facility. The paper therefore recommends as follows:

- Efforts should be made by the present and succeeding Governments to sustain the microcredit loan scheme towards eradication of poverty in the Nigerian society.
- The scheme should have zero tolerance for corruption to ensure its survival. Hence, there should be a close watch on all the stake-holders against any form of corruption in execution of the project and culprits should be dealt with accordingly.

- $\quad$ There should be transparency and strict adherence to the terms of the loan contract by the two parties.

- Aside disqualifying defaulters for subsequent loans, a more measurable sanction should be imposed on defaulters to serve as deterrents to others.

- The Government should delimit number of beneficiaries to embrace all qualified needy. However, arrangement could be made to avail the needy with the loan facility in turns of one group after the other.

- The 'TraderMoni' facility should not be confined to the urban markets but extended to the rural settings as well.

\section{REFFERENCES}

1. "Nigeria Poverty Statistics and Poverty Rate in Nigeria”. (2019). Culled from https://naijaquest.com/nigeria-poverty-statistics accessed on $12^{\text {th }}$ November.

2. "Nigeria has the highest rate of extreme poverty globally" (2019). Culled from http://qz.com/africa/1313380/nigeria-has-thehighest-rate-ofextreme-poverty-globally dated $25^{\text {th }}$ June, 2018 accessed on $12^{\text {th }}$ November.

3. Mustapha, H. (2001). "Poverty Alleviation Programmes in Nigeria: Issues and Challenges", International Journal of Development Research 4(3). March, 717 - 720. Also available online at http://www.journalijdr.com accessed on $12^{\text {th }}$ December, 2019.

4. Ohazuruike, K. (2019). Income Distribution and Income Inequality in Nigeria: Bridging the Gap through Trader Money (The Buhari Model), Issues, Challenges and Prospects. Uluslararast Sosyal Bilimler Dergisi, 3(15), 100-121.

5. Centre for Democracy \& Development. (2019). Assessment of the Effectiveness of Government Policies and Programmes on Economic Growth and Development 2015 - 2019, 19 retrieved from https://www.cddwestafrica.org/wp-

content/uploads/... PDF accessed on $20^{\text {th }}$ N0vember, 2019.

6. National Social Investment Office. (2019). "Investing in People: A brief on the National Social Investment Programmes in Nigeria"; March 2019 cited in Centre for Democracy \& Development, Assessment of the Effectiveness of Government Policies and Programmes on Economic Growth and Development, 2015 - 2019, 19

7. "Top Federal Government Empowerment Programmes in Nigeria" dated October 15, 2019 retrieved from https://campustimesng.com/top- 
federal-government-empowerment-programmes-innigeria accessed on 14th November, 2019.

8. “'Trader Moni'. (2019). Federal Government Empowerment Scheme" retrieved from https://'TraderMoni'.ng accessed on $14^{\text {th }}$ November, 2019.

9. Ayogu, G. I., Abasi, U., \& Ecoma, L. (2019). Tradermoni Micro-Credit scheme and poverty reduction in Nigeria. International Journal of Advanced Research in Management and Social Sciences, 8(4), 197-208.

10. Centre for Democracy \& Development. (2019). Assessment of the Effectiveness of Government Policies and Programmes on Economic Growth and Development 2015 - 2019, 19.

11. Abdul, W.Y.(2019). "Best Empowerment Programmes in Nigeria: Full List \& Details" culled from https://nigerianinfopedia.com.ng dated October 22, 2019 accessed on $14^{\text {th }}$ November, 2019.

12. Ijaiya, G. T., Ijaiya, M. A., Bello, R. A., \& Ajayi, M. A. (2011). Economic growth and poverty reduction in Nigeria. International Journal of Business and Social Science, 2(15), 147-154.

13. Anne, M.G., Anju, M., Priya, N., \& Rekha, M.(2019). "Understanding and Measuring Women's Economic Empowerment" culled from http://www.icrw.org/publications accessed on $14^{\text {th }}$ November, 2019.

14. Ijaiya, G. T., Ijaiya, M. A., Bello, R. A., \& Ajayi, M. A. (2011). Economic growth and poverty reduction in Nigeria. International Journal of Business and Social Science, 2(15), 147-154.

15. World Bank Report on Nigeria Economy. (2019). "Nigeria Overview" retrieved from www.worldbank.org updated $13^{\text {th }}$ October, 2019 and accessed on $12^{\text {th }}$ December, 2019.

16. Maurice, W. (2007). (ed.), Oxford Dictionary and Thesaurus (Oxford: Oxford University Press, 2007), 800.

17. Encyclopedia Americana, "Poverty" 22 (Connecticut: Scholastic Library Publishing Inc., 1989), 495 - 496.

18. Professor Y. Osinbajo. (2019). Vice President, Federal Republic of Nigeria, Sobi 101.9 FM Radio live Programme transmission $7^{\text {th }}$ December, 2019. Available also online at https:/elombah.com/'TraderMoni'-over-1-5million-petty-traders-nation-wide-nowbeneficiaries accessed on 12th December, 2019.

19. Ifeanyi, O. (2019). The Punch Newspaper, $21^{\text {st }}$ December, 2018. Available also online at https://www.pressreader.com accessed on $25^{\text {th }}$ November, 2019.

20. Afolabi, O. (2019). "FG, BoI launch "TraderMoni", in Lagos with N10, 000 loans for grabs”, Bussiness a.m. 20 August, 2018. Available also online at www.pressreader.com accessed on $25^{\text {th }}$ November.
21. "Prof Osinbajo. (2019). Launches 'TraderMoni. In Owerri” culled from https://www.'TraderMoni'.ng accessed on $25^{\text {th }}$ November, 2019 and "FG, BoI launch TrderMoni in Osun" in This Day

Newspaper, $4^{\text {th }}$ September, 2018 available also online at https://www.pressreader.com accessed on $25^{\text {th }}$ November, 2019.

22. "Vice President, Yemi Osinbajo launches the 'TraderMoni' and MarketMoni in Anambra" in The Guardian Newspaper, $8^{\text {th }}$ May, 2019 available also online at guardian.ng accessed on $25^{\text {th }}$ November, 2019.

23. Ogbette, Afamefuna Samuel, Bernard-Oyoyo Chimere and Okoh, Joel Ogechukwu, "'TraderMoni' Scheme and the 2019 Elections in Nigeria", Journal of Public Administration 1(2), 2019, $1-5$.

24. "How to Apply/Register for "TraderMoni'" FG Loan Scheme" culled from https://www.sprkgist.com on $28^{\text {th }}$ November, 2019.

25. ibid

26. 'Steps on How to Pay Back Your 'Trader Moni' Loan and Get another One" retrieved from https://www.basedonnews.com accessed on $12^{\text {th }}$ November, 2019.

27. "How to Pay Back 'TraderMoni' Loan. (2019)." Retrieved from https:www.efficiencyview.com accessed on $12^{\text {th }}$ November, 2019.

28. "BoI Rolls Out Repayment Scratch-Cards for 'Trader Moni' and MarketMoni Loans”.(2019). The Guardian Newspaper, $3^{\text {rd }}$ April, 2019.

29. Abdus-Samici Imam, A.(2003). "The Rights of a Woman to Acquisition, Ownership and Disposal of Property: The Shari ${ }^{c}$ ah Perspective" Ph. D. Thesis, University of Ilorin, 2003, 47.

30. Opeloye, M. O., A Dictionary of Peoples and Places in the Qur'an (Lagos: West African Publishers Limited, 1996), 109.

31. Al-Imam, Jalal-ud-Din Al-Mahaly., \& Al-Imam Jalal-ud-Din As-Soyuty, Tafsir Al-Jalalayn 2 trans. Muhammad Anis Gad Khalil (Egypt: Dar AlManar, 2010), 1122.

32. Muhyid-Din, Y.B. (2002). Sharaf An-Nawawi, Riyad-us-Salihina min Kalam al-Mursalina. Hadith Nos. 542 and 543 (Cairo: Shirkah al-Qudus linashr wa Tawzic, 2002$), 188$.

33. ibid, Hadith No. 540.

34. Aliu, B. (1998). "Implication of Zakat for Aggregate Investment in a Muslim-Dominated Economy", Ilorin Journal of the Humanities, 1(1), 129.

35. Nisthar, S., Mustafa, A. M. M., \& Nufile, A. A. M. (2019). "An Analysis of Socio-Economic Empowerment of Women in the Light of Islamic Perspectives" PDF culled from https://www.researchgate.net/publications/3277438 69 accessed on 14th November, 2019.

36. "Osinbajo Storms Kwara ..." (2019). With 'TraderMoni' retrieved from https://punchng.com and "Excitement Galore as VP Osinbajo Launched 
'TraderMoni' in Ilorin" retrieved from statehouse.gov.ng accessed on $10^{\text {th }}$ December, 2019.

37. "Thugs Disrupt 'TraderMoni'. (2019). Scheme in Ilorin" retrieved from https://www.pulse.ng accessed on $10^{\text {th }}$ December, 2019.

38. Abdul, F.O.(2019). ('TraderMoni' activation agent, Mandate Market, Ilorin), interviewed $14^{\text {th }}$ December, 2019.

39. Ogbette, A. S., Bernard-Oyoyo, C., \& Okoh, J.O. (2019). 'Trader Moni' Scheme and the 2019 Elections in Nigeria", Journal of Public Administration, 1(2), 2019, 1 - 5. See also Dayo Peters, "TraderMoni is Not Vote Buying Afterall" retrieved from https://www.pmnewsnigeria.com accessed on $29^{\text {th }}$ November, 2019.

40. Abdur, Rahim, M. A. (1958). The Principles of Muhammadan Jurisprudence (Lahore: The AllPakistan Legal Decisions, 1958), 318.

41. As-Sayyid Sabiq.(1992). Fiqh 'us-Sunnah III (Beirut: Dar al-Fikr, 1992), 182
42. Uthman, B. Hasanayn Bariy al-Ju' ${ }^{\mathrm{c}}$ aliy Al-Maliki, Siraj 'us-Salik, Sharh Ashal'ul Masalik II (Beirut: Dar Al-Fikr, 1972), 143.

43. Mannan, M. A. (1986). Islamic Economics: Theory and Practice (Cambridge: Hodder and Stoughton, 1986), $214-217$.

44. Abubakr, Jabir, Al-Jaza'iri. (1999). Minhaj AlMuslim (Beirut: Dar Al-Fikr, 1999/1420 AH), $335 \mathrm{ff}$.

45. Submissions at the Interactive gathering with selected women beneficiaries in a focus group discussion held on $19^{\text {th }}$ December, 2019 at the Mandate Market, Ilorin.

46. Madam Falilat Ayinke Bamidele (a non-beneficiary trader, Mandate Market, Ilorin) interviewed on $12^{\text {th }}$ December, 2019.

47. Kilani, A. R. O. (1994). Riba (Interest) in Nigeria Economic System (Port Harcourt: Pam Unique Publishers, 1994), 6.

48. Muhammad, M.K. (1994). (trans.), The Translation of the Meanings of Summarized Sahih Al-Bukhari (Riyadh: Dar-us-Salam Publications, 1994), 498. 